\title{
Implications of Womenomics on the Relationship between Female and Male Workers in the Professional and Social Environment: A Preliminary Study
}

\author{
Dewi Andika Setiawaty ${ }^{1}$ and Asra Virgianita ${ }^{2}$ \\ $\left\{{ }^{1}\right.$ dewiandikasetiawaty@gmail.com, ${ }^{2}$ asrahiui@ui.ac.id $\}$ \\ ${ }^{1,}$ School of Strategic and Global Studies, Universitas Indonesia, Indonesia \\ ${ }^{2}$ School of Strategic and Global Studies and Faculty of Social and Political Sciences, \\ Universitas Indonesia, Indonesia
}

\begin{abstract}
This article analyses the implications of Prime Minister Shinzo Abe's womenomics policy on the relationship between female and male workers in Japan in professional and social environments. The objective of this study is to explore how Shinzo Abe's womenomics affects the relationship between female and male workers in professional and social environments. The conceptual framework used is the concept of patriarchal culture in order to find out the influence of patriarchal culture on the implementation of womenomics in Japan, considering that Japanese society still holds patriarchal culture in their social interaction. This article suggests that the dominance of patriarchal culture has prevented the implementation of womenomics from giving effect to changes in the way people view women's position. This article is a qualitative research with the data collected using literature study / literature review technique. This article shows that womenomics policy, in spite of the claim of its success and capacity to increase Japanese economic growth, has implications with regard to the relationship between female and male workers in Japan. Womenomics has a positive impact in terms of increasing number of female workers thus allowing female workers to reach high positions in the professional work such as managers. However, the patriarchal culture retained by the community has undermined womenomics as a mere tool for achieving Japan's economic development targets (economic policy), and is not related as an effort to improve the position of women in social and work environments (gender mainstreaming).
\end{abstract}

Keywords: Womenomics, patriarchy, gender equality

\section{INTRODUCTION}

For almost two decades, Japan had to face economic stagnation and low Gross Domestic Product (GDP) growth. However, since the 2000s, there has been a positive growth trend in Japan's GDP (see chart 1). Chart 1 shows that the GDP growth has fluctuated. The increase in the previous year is always followed by a decline in the following year. The sharpest decline 
in Japanese GDP occurred in 2009, as a result of the 2008 global economic crisis (Farndale, 2008). The decline is the lowest rate of decline in Japan's GDP since World War II.

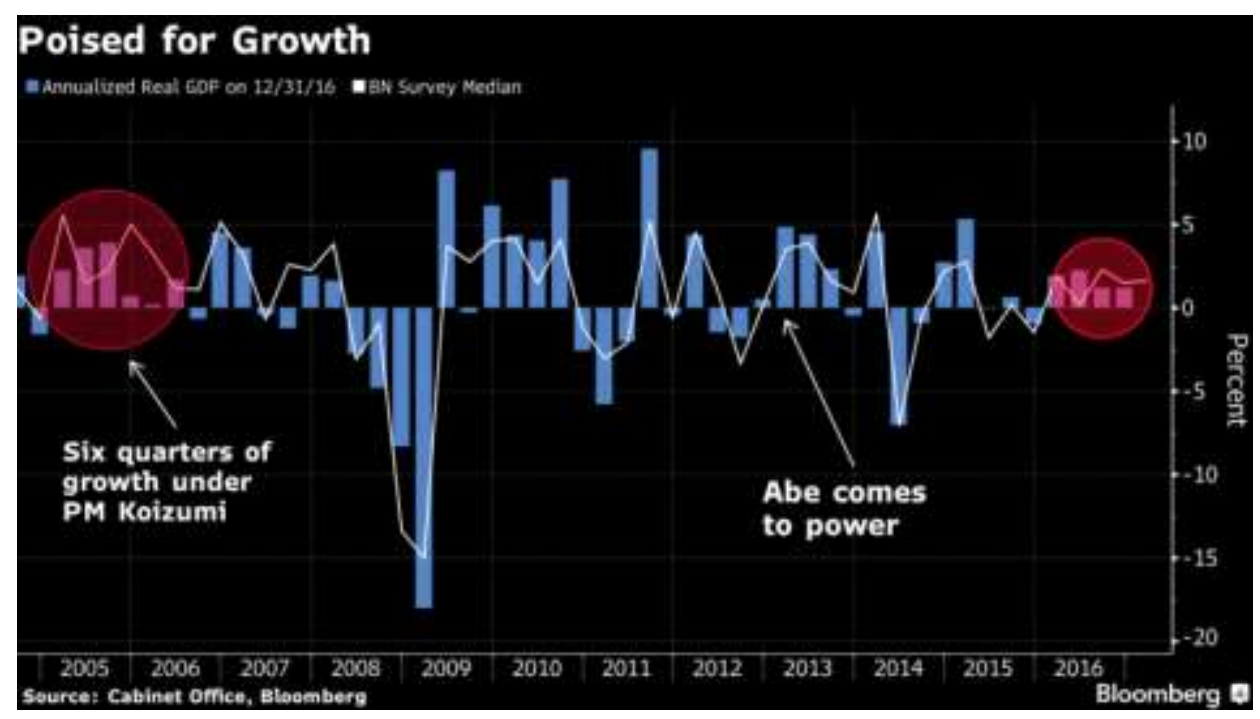

Figure 1. Japan`s GDP growth rate in 2004-2016 (\%)

Source: https://www.bloomberg.com/news/articles/2017-05-16/japan-is-set-for-its-longest-run-of-economic-growthin-a-decade (Ujikane, 2017)

Several policies have been formulated to solve the problem. Under the leadership of Prime Minister Shinzo Abe (2012-present), the Japanese Government has launched the idea of economic policy that aimed at boosting Japanese economic sector. The policy created by PM Shinzo Abe is known as Abenomics (Yoshino and Taghizadeh, 2014). Shinzo Abe has declared that his current administration would prioritize Japan`s economic revitalization. "With strength in this cabinet, I will implement a firm monetary policy, accompanied by flexible fiscal policy and a growth strategy that encourages more private investment. With the three pillars of policy, the expected results will be achieved, "Abe told in a news conference in Tokyo (Vivanews, 2012). The three pillars of Shinzo Abe's economic policies are aggressive monetary policy, flexible fiscal policy and growth strategies (Yoshino \& Taghizadeh, 2014).

One of Shinzo Abe's policy to improve the Japan`s economy is the major focus of this research. The policy is known as womenomics (Chanlett and Nelson, 2014) which is an effort that needs to be applied with regard to social welfare, economy, and increasing the role of women in achieving gender equality in Japan. The implementation of the policy has been welcomed by women in Japan with the rate of female workers in Japan has increased significantly since 2012 to reach $64.7 \%$ in 2015 , above the OECD average of $58.5 \%$ (The Secretary-General of the OECD, 2017). The climb of number of women working in Japan shows that there are quite a number of women in Japan who want to become career women.

In contrast with increased of women labor participation rates, male labor participation rates only increased slightly. Although male labor participation rate is still high, but if seen from the aspect of increasing labor participation from year to year, women labor participation has seen an increase. 


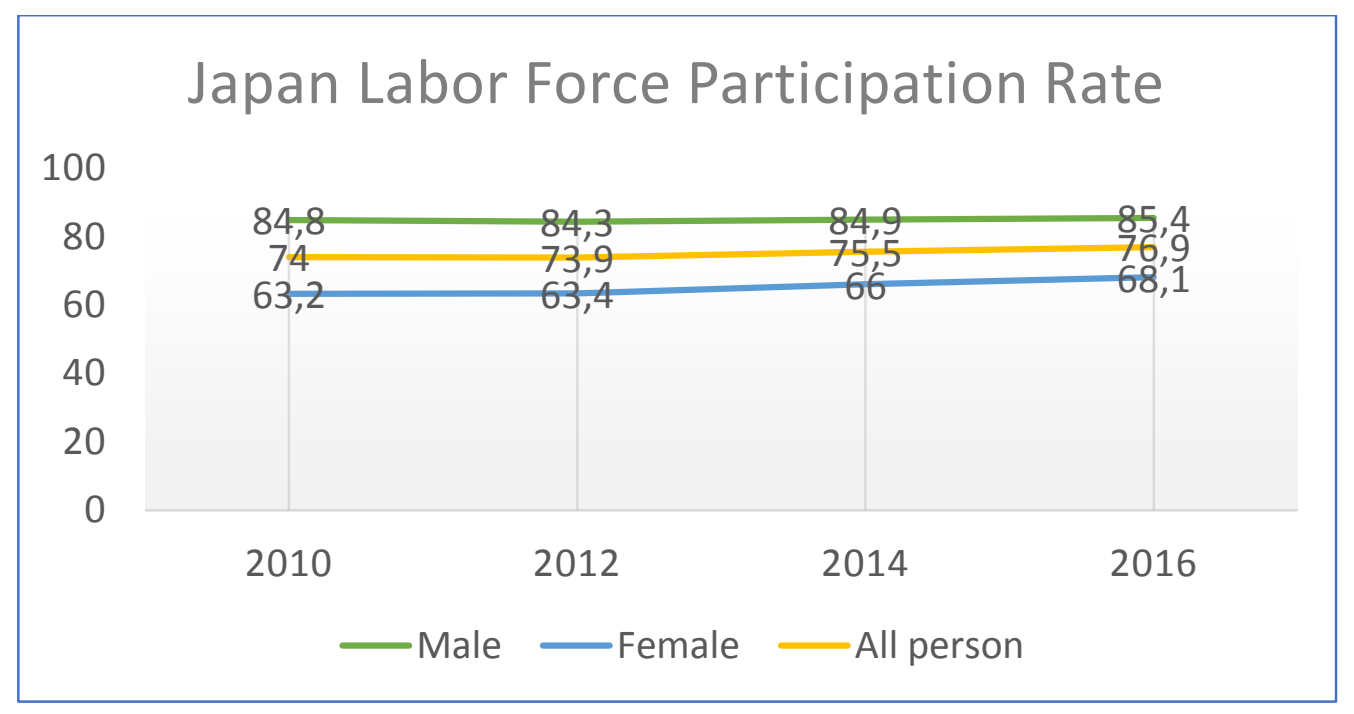

Figure 2. Japan Labor Force Participation Rate (\%)

Source: https://stats.oecd.org/Index.aspx?DataSetCode=LFS_SEXAGE_I_R\# (OECD Stat, 2017)

Chart 2 shows an increase of $63.4 \%$ in female labor participation in Japan in 2012, increasing to $68.1 \%$ in 2016. Male labor participation in Japan was $84.3 \%$ in 2010 which increased to $85.4 \%$ in 2016 . Women labor participation increased by a greater percentage compared to men from 2012 to 2016, which was around 5\% for female, while male work participation only increased by about $1 \%$. If this continues in the following years, the possibility for Japanese women to enter the working world will be greater.

Based on the initial explanation above, this article analyse Shinzo Abe's womenomic implications on the relationship between female and male workers in Japan and why it happens. This article argues that in spite of the adoption of womenomics, in reality of this policy cannot eliminate patriarchal culture in Japan due to the strong and rooted patriarchal culture.

\section{LITERATURE STUDY}

This point will review several articles that have the key words of "patriarchy" and "womenomics" as the benchmarks of the extent of discussion on patriarchy and womenomics in Japan by previous studies. It aims to find the empty space that can be filled by discussing the same theme, namely womenomics and patriarchy.

\subsection{Patriarchy in Japan}

Japan has now become a modern country but they maintain their traditional culture. The Japanese society observes patriarchal culture in the structure of society, not only in the domestic and community life but also in the work environments. Some researchers are interested in researching the patriarchal culture of Japanese society which is still strongly 
observed today. The studies are not only focused on Japanese patriarchal culture, but also related to other factors as per the researchers' disciplines. Examples of articles that discuss patriarchy in Japan include the following articles.

Miyuki Kazui (1997) and Sheldon Garon (2010) discuss the role of mothers in Japan in terms of parenting. Based on the patriarchal culture observed by Japanese society the mother has a major role in parenting. Miyuki Kazui writes about the level of stress experienced by Japanese mothers in the caregiving period due to the demands for their role in educating children to be great and successful. In his paper Miyuki Kazui focuses on the analysis of the influence of maternal stress level on child development which was seen from the aspect of psychology. Sheldon Garon in his article adds about the role of men in Japan. Sheldon Garon writes that in a patriarchal culture, men are the leaders, family heads, and have more power than women while women are always subordinate to men and play an important role as mothers who are tasked with educating children and managing domestic affairs

Yumiko Ida (2006) discusses Japanese youth that tries to change the concept of masculinity in the Japanese patriarchal culture. They use "feminine" strategies and aesthetics to create new masculine identities. Yumiko Ida argues that young people find strategies to distance themselves from the concept of conventional masculinity and create alternative gender identities. The reaction of the young people is driven by the anxiety about the concept of conventional masculinity that is difficult to maintain in modern Japan.

Using the same theme of patriarchy in Japan, Michael Rush (2015) in analyzing patriarchal culture in Japanese society discusses the imbalance of the role of fathers in childcare. Michael Rush's research aims to look at comparisons of social policies and the hypotheses argues that creating the rights as citizens for men that have the role of being fathers to participate and have time in care is the most effective way to increase father involvement in parenting. Michael Rush argues that the enactment of the policy may increase birth rates in Japan.

Discussing the same problem with Michael Rush (2015) regarding the role of father in Japan in parenting, Ms. Tingting Tan (2016) writes about the increasing involvement of fathers in care as an implication of family-friendly policies. However, this has the effect of increasing father's depression for thinking to find the balance between work and family. In his research, Ms. Tingting Tan highlights three findings that cause depression for men, namely hierarchical culture in the company, "male-headed" culture in public setting and "housewife keeping" in personal setting.

The articles above indicate different research focuses as seen from the year the articles are written. In the early 1990 s and 2000s, researches focused on the role of men and women that observe the patriarchal culture as suggested by Miyuki Kazui (1997) and Sheldon Garon (2010). However, since 2006 there have been efforts of the Japanese community to redefine the roles of men and women in Japan and create an alternative culture, as seen from the article written by Yumiko Ida (2006). Under Prime Minister Shinzo Abe's administration, bigger focus is put on the role of fathers in childcare. This era marks the awareness that fathers also play a role in childcare as shown by, among others, articles written by Michael Rush (2015) and MS Tingting Tan (2016).

\subsection{Womenomics}

Chelsea Szendi Scheader (2014) writes an article on womenomic which evidently is not well realized to achieve gender equality. The societal norms still hamper women to assume high positions. Although Shinzo Abe has stated that he provides opportunities for women to enter politics, in reality women can only reach non-regular employment positions. Only 
women from elite background can assume positions in politics, managerial duties, and other high level positions.

Another article with similar idea is written by Helen Macnaughtan (2015) which discusses the idea of gender equality through womenomics which is not fully achieved, because of the rigid Japanese conventional culture which shows gender inequality. Helen Macnaughtan argues that conventional culture that does not support the idea of gender equality has forced women to work as non-regular workers.

Emma Dalton (2017) in her article adds an analysis of Chelsea Szendi Scheader (2014). While Chelsea Szendi Scheader focuses on female workers, especially in political setting, Emma Dalto adds a discussion on womenomics which implies that women further exacerbate the bipolarization of Japanese women into two groups: small elite minorities who are able to assimilate with masculinistic work patterns and a large majority of women categorized into less secure and unsafe 'non-regular' work groups, that are denied important useful access.

Based on the discussion of articles on womenomics, it can be seen that the discussion on womenomics is focused on its implications for women. The situation of women in Japan after womenomics is applied is highlighted more because womenomics is a breakthrough with regard to the role of women in the society based on patriarchal culture.

The articles above conclude that patriarchal culture is still maintained by the Japanese society. Before womenomics, the matter highlighted was the division of roles of men and women in Japan as dictated by patriarchal culture. As time went by, Japan turned into a modern state, some Japanese people tried to change the thinking of the Japanese community based on patriarchal culture to survive in the social environment. After womenomics, scientific articles focus on the impact of womenomics on women and the extent of success of the involvement of fathers in childcare because womenomics also provides an opportunity for fathers to participate in childcare.

Compared to the focus of the articles reviewed, this article puts a little different different focus. Although it has similarities in conceptual terms which also discuss patriarchal culture, this article looks at the implications of womenomics on women and men workers in the workplace and society which is different from the previous article which discuss the implications of womenomics on women.

\section{CONCEPTUAL FRAMEWORK AND METHOD}

The analysis of this article uses the concept of patriarchal society because the Japanese society is a society that still holds fast to their hereditary patriarchal culture. Japan is a country that has been subject to modernization but refuses to abandon its culture values. Japan has adopted western culture since they are under control of the United States (US). Japan openly accepts modernization from western culture, but still filters influences to find out whether or not that culture matches its traditional culture. Japan culture values come from Confucianism which makes Japan a patriarchal society.

Bashin (Sugihastuti and Itsna, 2010) suggests that patriarchy is a system of male domination and superiority towards women. Patriarchy carries an ideology which states that men are more appreciated than women, women must be controlled by men, and women are part of men's property. This ideology creates a social construction ruling that women are put under the control of men and men are in full control of women. Patriarchy is the power of the father: a familial-social, ideological, political system (Eisenstein, 1984). 
According to Carl Jung, a neo-Freundian, men and women do not have actual psychological differences. The differences surface because of cultural influences and beliefs in the society. Jung argues that culture, especially the patriarchal Europe, emphasizes the need for differentiating the roles of males and females (Handayani and Ardhiana, 2008). Masculine is a character commonly associated with men while feminine is associated with women.

The Japanese society believes in a concept suggesting that male masculinity is seen through its strength, power, and ownership represented through the figure of salaryman. For Japanese people in late 1950s and 1960s, the salaryman figure was associated with a "bright new life" (Roberson, 2003). Japanese young girls hoped to marry a salaryman (Roberson, 2003). The new order salaryman is not only a way of life for people who come from large organizations, but also a model that influences the way of life of others (Roberson, 2003). However, 30 years later the image of salaryman turned into a hard worker who work long hours in large companies, such as Mistubishi, go drinking with colleagues or clients after returning home from work and playing golf with them on weekends and rarely spend time at home with children and wives, let alone do things around the house, such as cleaning the house, sweeping yards, or changing diapers (Roberson, 2003).

After looking at the description of the research concept, this article will use qualitative research method as it aims to explore the implications of the relationship between female and male workers in Japan and to identify the relationships that lead to the less participation of men compared to women. Literature study is conducted to answer the question on the implication of womenomics policy on the relationship between female and male workers in Japan.

\section{RESPONSE OF THE SOCIETY AND EMPLOYERS TO WOMENOMICS}

The implementation of womenomics by Prime Minister Shinzo Abe since the outset of his administration in 2012 has received various forms of responses from the public and business. At this point, we will explain the forms of response from the public and businesses after the implementation of womenomics in Japan. However, before that, we will first explain the concept of womenomics

\subsection{The concept of womenomics.}

Womenomics in the three arrows of Abenomics policy is part of structural reforms (Glod, 2013). The main objective of womenomics structural reform is to provide a favorable work environment for women in the professional world when caring for children and not (Goldmand Sashs Group Inc., 2010). In addition, it also aims at improvising the business environment in improving the progress and career role of women in the professional world (Goldmand Sashs Group Inc., 2010). The increase in the scope of women's employment opportunities in PM Abe's policy is expected to change the structure of the position and views that exclude women in the professional world that is not in accordance with the principles of gender equality and justice.

The involvement of women in the professional world is a form of gender equality and justice to realize equality and justice rights towards harmonization. According to Kathy Matsui as the Chief Japan Equity Strategist at Goldman Sachs in 1999, "involving women in 
the professional world, especially in leadership functions, will increase the value of Japanese GDP" (Matsui, 2010). The main objective of womenomics is to increase the number of Japanese female workers to achieve economic growth and stability. Womenomics acts as a solution to the challenges of Japan which is experiencing recession and stagnating economic growth caused by the world financial crisis. The factors of reduced number of productive workforce and declining birth rate are also other reasons for implementing womenomics.

PM Abe has explained in his speech to the United Nations General Assembly (shortly after being sworn-in as the Prime Minister) that the focus and concentration of the formula for economic improvement during his administration is to include and bring women to the Japanese professional world (MOFA Japan, 1995) towards active participation of women as the core of growth and development strategies, and elimination of discrimination that women workers often experience in the workplace in womenomics (Gender Equality Bureau Japan, 2013). Womenomics is a policy in Japanese women's reform in the professional world during PM Abe's tenure which focuses on empowering women as part of the solution to the problem of Japanese stagnating economy (Matsui, 2005). Japanese people now have awareness to create gender equality to empower women to believe they are able to become members of the top-class society with resources capable of competing in the global market through their participation in the world of work (Salisbury and Peter, 2013).

Womenomics is a policy that connects the objectives of market liberalization as broadly as possible without a hindrance to the state which is met with a normative domestic role as an effort to create public regulation to eliminate problems that hinder the development and expansion of market freedom (Rapley, 2007). It can be seen that the principle of embedded liberalism as Japan's effort to create regulation reflected in womenomics is a form of intervention on public affairs with the aim of transforming the structure of society to equal prosperity. Prosperity is the goal not only for the welfare of the Japanese society, but also to strengthen and revive Japanese economic growth. The declining employment figures have an impact on production in trade; thus increasing the role of women in the professional world can address the challenges of companies and the need for labor in moving the wheels of growth.

Strategies similar to Shinzo Abe's womenomics have existed since the administrations of Prime Minister Hashomoto and Koizumi, but their administration focused more on what women can do for Japan which is not an attempt to create gender equality (Osawa, 1990). Prime Minister Shinzo Abe does not only attract women to contribute, but also attempts to create changes in the construction of society towards equality between women and men (Osawa, 1990). Quoting from the Women in Business Summit 2013, Prime Minister Shinzo Abe stated "I have placed the strategy for women at the center of the strategy for growth." (Aoki, 2014).

Prime Minister Shinzo Abe has also collaborated with the Gender Equality Bureau Cabinet Office through 6 strategies aimed at achieving womenomics as a policy that can make people more responsive to gender namely: (Gender Equality Bureau Japan, 2013)

- Increasing women's participation in employment.

- Achieving a 30\% percentage of women's role in leadership positions by 2020.

- Increasing the percentage of women returning to the professional world after having the first child.

- Accelerating and increasing the construction of childcare and after school club facilities.

- Increasing the percentage of fathers taking childcare leave.

- Reducing companies that have working hours of more than 60 hours per week. 
Shinzo Abe's 6 strategies through womenomics does not merely target the achievement of gender equality for balance in the work and family environments that include the public and domestic sectors. It is designed to achieve the target of increasing the availability and presence of women in government at national and local levels. In addition, the strategy also refers to recommendations from the United Nations (UN) so as to actualize the universal values of equality (Gender Equality Bureau Japan, 2013).

\subsection{Public response}

In 2008-2010 the percentage of unemployment in Japan touched the rate of 5.6\% which is the highest in the last two decades, but after the policies of Prime Minister Shinzo Abe were put into effect, the decline continued in a sustainable manner and in 2015 Japan's unemployment rate was $3.1 \%$ (Trading Economics, 2016). After the implementation womenomics, the increase in full-time workforce has also showed a positive trend, reaching more than 2 million workers, up from the period before womenomics which was only around 1 million (Trading Economics, 2016a). This shows that the existence of womenomics brings positive impacts in the achievement of a two-fold increase in labors in recent years.

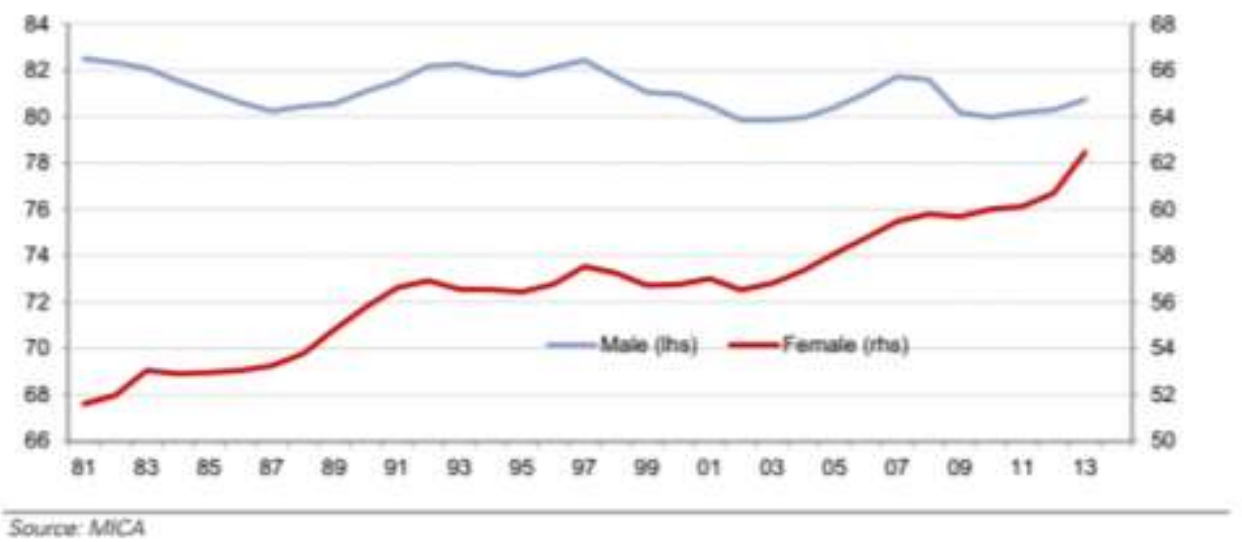

Figure 3. Percentage of Male and Female Work Participation (15-64 years) (Matsui, 2014)

The chart above shows that the percentage of increase in female employment participation reached $62.5 \%$ in 2013. It also shows the number that continues to increase from year to year. Male work participation shows very little increase in contrast to female work participation that increases significantly. Although male work participation is still higher, namely $64.3 \%$ compared to women at $62.5 \%$, the percentage of increase is not more than female workers from year to year.

The implementation of womenomics for the purpose of increasing the participation of women to work turns out to be filled by low-paying work positions, such as part-time jobs. Large companies like Toyota, are filled by only $4 \%$ women in managerial positions (Oda and Isabel, 2018). In 2016 a survey was conducted on several men, $45 \%$ of them agreed to the idea that women should stay at home (Oda and Isabel, 2018). In politics in Japan, 20 positions are reserved for women, but in reality there are only 2 positions occupied by women (Oda and Isabel, 2018).

In 2015, Seiko Noda nominated himself as Japan's Prime Minister, competing with Shinzo Abe, but Seiko Noda was defeated by Shinzo Abe. Seiko Noda said that it was "difficult" to 
make changes if "only men were involved". According to Seiko Noda, great structural reforms require the power of women to gain wide credibility and attractiveness (Pesek, 207).

The application of womenomics is a big hope for women to be economically independent and help their families' economy. After womenomics is implemented, women's work participation increases, even in low-paying work positions. However, Japanese men apparently disagree with the idea of giving women the opportunity to work and achieve high positions. According to Japanese men, women should stay at home as housewives.

\subsection{Employers' response}

The economic crisis has resulted in low Japanese economic growth and shifts in various economic and social aspects. The low economic growth has resulted in a low demand for employment. Due to economic uncertainty, many companies began to carefully recruit workers as full time workers. The economic crisis has caused many companies to change their human resources recruitment strategies, namely by employing a few new graduates and increasing the number of non-full time workers with certain employment contracts (Kosugi, 2004).

The company chooses non-regular workers because of low labor costs absence of social security for workers in this category, unlike regular workers which is profitable for companies because they can reduce the burden of labor welfare costs. Companies choose non-regular workers due to their flexibility or in other words the companies only require more workers in case of peak demand (Shirai, 2000).

The Human Resources recruitment strategy has continued to be implemented during Prime Minister Abe's administration because the strategy is able to increase the company's production and boost up Japanese GDP. Large-scale recruitment of non-regular workers are happy news for women in Japan along with the introduction of womenomics. A lot of women choose to be non-regular workers due to the time flexibility that allows them to take care of their family while working.

Only companies that need a lot of non-regular workers agree with womenomics. Some companies with more regular than non-regular workers do not agree with the notion that the career path of women should be equal to men. This belief is caused by the hierarchical culture within the company, making the presence of female workers merely a "profiling" activity driven by unrealistic targets, compared to the environment in which female workers and diversity are seen as competitive sources of excellence (Macnaughtan, 2015).

In conclusion, the public and employers have pros and cons with to the application of womenomics. Japanese women agree with pro-womenomics, but Japanese men are against it. From the business side, especially employers who heavily rely on non-regular workers in their production are favorable towards it because it helps increase productivity and the company only needs to pay a small expenses for the salaries of non-regular workers.

\section{IMPLICATIONS OF WOMENOMICS ON THE RELATIONSHIP OF FEMALE AND MALE WORKERS IN THE PROFESSIONAL AND SOCIETAL ENVIRONMENTS}

Implications are the consequences of implementing certain policies or activities that may give negative and positive results (Islamy, 2003; Silalahi, 2005). At this point, we will explain the implications of the application of womenomics in Japan on the relationship of female and 
male workers in professional and societal environments. The analysis shows that womenomics have negative implications for the relationship of female and male workers. These implications include the emergence of maternity harassment, single parasite and hikikomori.

\subsection{Maternity Harassment (MATAHARA)}

Although there has been a gender equality policy in the professional world and equal opportunities between men and women to achieve high career positions in the professional world, the practice of discrimination against women workers still exists. Womenomics policy still cannot be implemented properly, seeing Japanese culture that positions women under men. One of the consequences of discriminating women workers is maternity harassment (matahara) in 2013 (Ryan, 2015).

Matahara is known in Japan as mental and psychological abuse of women who are pregnant or women who have given birth (Hall, 2017). A survey conducted by The Japanese Trade Union Confederation (JTUC) in 2013 and 2014 showed that only about $20.5 \%$ of women in 2013 have heard the word matahara, but in the following year the figure increased to $623 \%$ (Ryan, 2015) . The survey results in 2014 show the results of 626 respondents from all over Japan, that $26.3 \%$ of women report that they have been the victims of matahara although in the previous year there were fewer victims namely around 25.6\% (Ryan, 2015)

One of the victims of matahara named Sayaka Osakabe is the first woman who has the courage to expose the issue of matahara to the media and sees so many victims besides herself. The numerous positive responses received by Osakabe with regard to her actions has encouraged Osakabe to take the initiative to establish an organization that may help victims of matahara, named MataharaNet (Ryan, 2015).

\subsection{Single parasite}

Single parasite is a term for children in Japan, whose age has entered the productive age, can live independently and earn income, but still live with parents and still ask for living expenses from parents (Sieg and Ami, 2017). The term was first coined by a Japanese sociologist named Masahiro Yamada in 1997. Based on this explanation, it can be interpreted that someone called a single parasite is a child who has entered a productive age, is able or unable to support his own life, not married, but still lives with parents.

According to the results of a survey of The Statistical Research and Training Institute in 2016, around 4.5 million Japanese aged between 35 years and 54 years live with their parents (Sieg and Ami, 2017). According to the data released in March 2017, the culmination of an increase in single parasites occurred in 2015 with among 50-year-old Japanese, 1 in 4 men and 1 in 7 women are not married and they live as single parasites (England, 2017).

There are differences in social burden between men and women in Japan regarded as single parasite. For women, the term single parasite does not overload their mentality, because in the Japanese patriarchal culture, women depend on their parents when they are not married and their husbands when they are married. After Prime Minister Shinzo Abe implements womenomics in Japan allowing women to have economic independence rights, there is anxiety for women if they continue to live with their parents although the percentage of women who experience anxiety is still small because of the strong patriarchal culture in the Japanese society. 
Unlike women, for men the term greatly burden their mentality. A man in Japan who has entered the productive age must be able to live independently, earn income and have permanent employment. This social rule will later have an impact on their anxiety to be seen and known by the surrounding community and lead to their greater desire to stay home and stay away from social interaction. This phenomenon in Japan is known as hikikomori.

\subsection{Hikikomori}

The hikikomori phenomenon coincides with the phenomenon of single parasites in Japan leading to curiosity whether these two phenomena are interdependent. Hikikomori are people who choose to isolate themselves from the social environment and still rely on parents to take care of them (Roch, 2018). According to The Japanese Ministry of Health, Labor and Welfare the definition of hikikomori is the condition of individuals who are depressed and isolate themselves from the society for a period of 6 months (Itou, 2003).

In 2016, a census carried out by the Japanese government suggests that around 54,000 people aged 15-39 years become hikikomori (Roch, 2018) because of the increasingly harsh competition in the professional world. For men, who in the community's view must earn income and have permanent works, it becomes a burden when they have tried, but fail to secure permanent jobs. The mental burden causes them to isolate themselves. In a patriarchal culture, men are required to live independently, have regular jobs and earn income, get married and be able to support their family with their income.

The intense implementation of womenomics has encouraged women to work - allowing them to be economically independently thus reducing dependence on men. This has harmed the Japanese male pride as the dominant party. As an escape, they withdraw from social interaction.

A Vietnamese journalist named Elan suggests that before encountering hikikomori in Japan, he thought they are edois and lazy, but after he met some hikikomori people, in fact they have their own perceptions and ways of wisely balancing themselves in their environment (Roch, 2018).

Based on the analysis, the strong and rooted patriarchal culture in Japanese society has hampered the implementation of womenomics. Although the Government has facilitated female and male workers to balance work and family, the opinion of Japanese society regarding the role of women and men that is still guided by patriarchal culture has exposed negative implications of the practices of womenomic in professional and social environments.

The patriarchal culture that demands men to be dominant and women to be subject to men has depressed individuals in Japan who fail. In the case of matahara, the competition between men and women in the professional world is a threat to male workers due to female domination, encouraging them to use verbal abuse to overthrow women and show their domination of women. Meanwhile, the cases of single and hikikomori parasites occur because of the failure of men to carry out their role as the dominant ones making them to stay away from the people of the surrounding environment to survive.

\section{CONCLUSION}

Womenomics is a form of mechanism to encourage the role of women in Japan in the professional world. Womenomics is also a new forum for gender responsive policies. Through data it can be explained that after womenomics, women's participation in the professional 
world shows positive progress which is a standard of the success of womenomics. However, the concept of patriarchal culture has hampered the application of womenomics with regard the process of transforming gender responsive Japanese society towards achieving a truly gender-minded society. The cultural clash has become a barrier in terms of Japanese social conditions towards the implementation of womenomics, as it can be concluded that the political and economic conditions have supported the implementation of Womemomics policy.

The influence of the strong patriarchal culture in the Japanese society has prevented womenomics to be implemented perfectly and eventually lead to several cases, such as matahara, single parasites, and hikikomori. The patriarchal culture that places men in a higher position than women has made many male workers feel competed and cannot accept if there are women workers who have higher positions. People who are unable to withstand the rigors of competition in the professional world choose to depend on their parents, and when the surrounding community finds that out, they withdraw from social interaction and become hikikomori.

As results, this study indicates that Shinzo Abe's womenomics is more economic in nature and not designed for gender equality. This Womenomics has negative implications in terms of relationship between female and male workers while in terms of economic development it shows positive impacts.

\section{ACKNOWLEDGEMENT}

This research based on grant scheme of PITTA (Publikasi International Terindeks untuk Tugas Akhir) 2018 or also known as Indexed International Publications for Final Projects toward Universitas Indonesia students. Thank you to Dr. Asra Virgianita as my advisor

\section{REFERENCES}

[1]. Yoshino, N., \& Taghizadeh Hesary, F. (2014). Three Arrows of'Abenomics' and the Structural Reform of Japan: Inflation Targeting Policy of the Central Bank, Fiscal Consolidation, and Growth Strategy.

[2]. Aoki, Mizuho. (2014, Mei). Abe Vows To Get More Women Into Workforce After Dismal Global Ranking. Japan Times, 27(5). Accessed from http://www.japantimes.co.jp/news/2014/05/27/business/economy-business/abevowsget-women-workforce-dismal-global-ranking/\#.VvVbIE8s78d

[3]. Chanlett-Avery, E., \& Nelson, R. M. (2014). " Womenomics" in Japan: In Brief. Current Politics and Economics of Northern and Western Asia, 23(4), 411

[4]. Dalton, E. (2017). Womenomics, 'Equality'and Abe's Neo-liberal Strategy to Make Japanese Women Shine. Social Science Japan Journal, 20(1), 95-105

[5]. Dasgupta, R. (2012). Re-reading the salaryman in Japan: Crafting masculinities. Routledge

[6]. DePaulo, B. (2018). Why "Parasite Singles" Is More Than an Insult. Psych Central. Accessed from https://blogs.psychcentral.com/single-at-heart/2018/01/why-parasitesingles-is-more-than-an-insult/

[7]. England, Charlotte. (2017, April). Japan: More than four million middle-aged 'parasite singles' still live with their elderly parents. Independent, 20(4). Accessed from 
https://www.independent.co.uk/news/world/asia/japan-parasite-singles-four-millionmiddle-age-parents-live-childbirth-rate-unmarried-unemployed-a7692256.html

[8]. Farndale, Nigel. (2008, Desember). Lehman Brothers collapse: How the worst economic crisis in living memory began. The Telegraph, 23(12). Accessed from http://www.telegraph.co.uk/finance/recession/3917584/Lehman-Brothers-collapseHow-the-worst-economic-crisis-in-living-memory-began.html

[9]. Garon, S. (2010). State and family in modern Japan: A historical perspective. Economy and Society, 39(3), 317-336

[10]. Gender Equality Bureau Japan. (2013). Main Policies. Accessed from http://www.gender.go.jp/english_contents/mge/index.html

[11]. Gender Equality Bureau Japan. (2013, Juni). Toward Active Participation of Women as the Core of Growth Strategies. White Paper on Gender Equality. Accessed from http://www.gender.go.jp/english_contents/about_danjo/whitepaper/pdf/2013-01.pdf

[12]. Hall, Ava. (2017, Oktober). Stamp out maternity harassment. Japan Times, 6(10). Accessed from https://www.japantimes.co.jp/opinion/2017/10/06/reader-mail/stampmaternity-harassment/\#.W8JX-ZiZ2Zx

[13]. Iida, Y. (2005). Beyond the 'feminization of masculinity': transforming patriarchy with the 'feminine'in contemporary Japanese youth culture. Inter-Asia Cultural Studies, $6(1), 56-74$

[14]. Itou, Junichirou (2003). Shakaiteki Hikikomori Wo Meguru Tiiki Seisin Hoken Katudou No Guide-line [Guideline on Mental Health Activities in Communities for Social Withdrawal] (in Japanese). Tokyo: Ministry of Health, Labor, and Welfare

[15]. Kazui, M. (1997). The influence of cultural expectations on mother-child relationships in Japan. Journal of applied developmental psychology, 18(4), 485-496.

[16]. Macnaughtan, H. (2015). Womenomics for Japan: is the Abe policy for gendered employment viable in an era of precarity?. The Asia-Pacific Journal, 13(12/1)

[17]. Macnaughtan, H. (2015, Agustus). Is Abe's womenomics working?. East Asia Forum, 27(8). Accessed from http://www.eastasiaforum.org/2015/08/27/is-abes-womenomicsworking/

[18]. Matsui, Kathy, dkk. (2005, Oktober). Womenomics: Japan's Hidden Asset. Goldman Sachs, 19(10). Accessed from http://www.goldmansachs.com/our-thinking/investingin-women/biospdfs/womenomics-pdf.pdf

[19]. Matsui, Kathy, dkk. (2010, Oktober). Womenomics 3.0: The Time is Now. Goldman Sachs, 1(10). Accessed from http://www.goldmansachs.com/our-thinking/investinginwomen/bios-pdfs/womenomics-pdf.pdf

[20]. Matsui, Kathy, dkk. (2014, May 30). Womenomics 4.0: Time to Walk the talk. Goldman Sachs

[21]. MOFA Japan. (1995, Mei). Concluding Observations of the Committee on the Elimination of Discrimination against Women: Japan. MOFA Japan, 31(5). Accessed from http://www.mofa.go.jp/policy/human/conv_women2.html

[22]. Oda, Shoko dan Isabel Reynold. (2018, September). What Is Womenomics, and Is It Working for Japan?. Bloomberg, 20(10). Accessed from https://www.bloomberg.com/news/articles/2018-09-19/what-is-womenomics-and-is-itworking-for-japan-quicktake

[23]. Oda, Shoko, \& Isabel Reynold. (2018, September). What Is Womenomics, and Is It Working for Japan?. Bloomberg, 20(9). Accessed from https://www.bloomberg.com/news/articles/2018-09-19/what-is-womenomics-and-is-itworking-for-japan-quicktake 
[24]. OECD, Stat. (2017, Mei 21). Labour Force Statistics. Accessed from https://stats.oecd.org/Index.aspx?DataSetCode=LFS_SEXAGE_I_R\#

[25]. Osawa, Mari. Government Approaches to Gender Equality in the Mid-1990s, Vol. 29, No. 1, Special Issue on Controversial Issues in Japanese Politics and Society. Lynne Rienner Publishers. Accessed from http://www.jstor.org/stable/42704494

[26]. Pesek, William. (2017, Agustus). Japan's 'womenomics' finally gets a face. Asia Nikkei, 21(8). Accessed from https://asia.nikkei.com/Politics/Japan-s-womenomicsfinally-gets-a-face

[27]. Rapley, John. (2007). Understanding Development: Theory and Practice in the Third World. St. Boulder: Lynne Rienner Publishers

[28]. Reality Check Team. (2018, February). Reality Check: Has Shinzo Abe's 'womenomics' worked in Japan?. BBC News, 17(2). Accessed from https://www.bbc.com/news/world-asia-42993519

[29]. Roberson, J. E., \& Suzuki, N. (Eds.). (2003). Men and masculinities in contemporary Japan: Dislocating the salaryman doxa (Vol. 56). Psychology Press

[30]. Roch, Laurence Butet. (2018, Februari). "Pictures Reveal the Isolated Lives of Japan's Social Recluses". National Geographic Chanel, 14(2). Accessed from https://www.nationalgeographic.com/photography/proof/2018/february/japanhikikomori-isolation-society/

[31]. Rush, M. (2015). Theorising fatherhood, welfare and the decline of patriarchy in Japan. International Review of Sociology, 25(3), 403-414

[32]. Ryan, K. (2015, Februari). Maternity Harassment in Japan: Ambitious Japanese Women Struggle To Balance Family And Career. The Diplomat, 11(2). Accessed from https://thediplomat.com/2015/02/maternity-harassment-in-japan/

[33]. Salisbury, Joyce E. dan Peter Seelig. (2013, Mei). Gender Roles in Japan: 17th and 18th Centuries. Accessed from http://www.chaminadelibrary.org/uploads/9/6/0/5/9605465/gender_roles_in_japan_17 th_and_18th_centuries.pdf

[34]. Shizuko, K., \& Sylvain, G. A. (1994). The" Good Wife and Wise Mother" Ideology in Post-World War I Japan. US-Japan Women's Journal. English Supplement, (7), 31-52

[35]. Sieg, Linda dan Ami Miyazaki. (2017, April). Japan's middle-aged 'parasite singles' face uncertain future. Japan Times, 20(4). Accessed from https://www.japantimes.co.jp/news/2017/04/20/national/social-issues/japans-middleaged-parasite-singles-face-uncertain-future/\#.W8JZTpiZ2Zw

[36]. Smith, R. J. (1987). Gender inequality in contemporary Japan. Journal of Japanese Studies, 13(1), 1-25

[37]. TAN, M. T. (2016, August). Postmodern Japanese Model: Struggling Father. In Academic International Conference on Multi-Disciplinary Studies and Education (p. 5)

[38]. The Secretary-General of the OECD. (2017, April). Employment: Improving The Labour Market Outcomes Of Women. Accessed from https://www.oecd.org/japan/japan-improving-the-labour-market-outcomes-ofwomen.pdf

[39]. Trading Economics. (2016). Japan Unemployment Rate. Jepang: Trading Economics. Accessed from http://www.tradingeconomics.com/japan/unemployment-rate

[40]. Ujikane, Keiko. (2017, Mei). Japan Is Set for Its Longest Run of Economic Growth in a Decade. Bloomberg, 17(5). Accessed from https://www.bloomberg.com/news/articles/2017-05-16/japan-is-set-for-its-longest-runof-economic-growth-in-a-decade 
[41]. Vivanews. (2012, desember 27). PM Baru Jepang Ingin Akhiri Stagnasi Ekonomi. Viva, 27(12). Accessed from http://www.viva.co.id/berita/dunia/377738-pm-barujepang-ingin-akhiri-stagnasi-ekonomi 